International Scientific Organization http://iscientific.org/

Chemistry International

www.bosaljournals.com/chemint/

\title{
Total petroleum and aliphatic hydrocarbons profile of the River Niger surface water at Okpu and Iyiowa-Odekpe regions in South-Eastern, Nigeria
}

\author{
Augustine Avwerosuo Chokor*
}

Department of Chemistry, Federal University Otuoke, Nigeria

*Corresponding author's E. mail: aachokor@gmail.com

\section{A R T T I C L E $\quad$ I N F}

\section{Article type:}

Research article

Article history:

Received February 2021

Accepted May 2021

Julay 2021 Issue

Keywords:

Total petroleum hydrocarbons

Source diagnostic ratio

GC-FID

River Niger

Biogenic

Anthropogenic contamination

\section{A B S T R A C T}

Total petroleum hydrocarbons (TPH) as well as the aliphatic profiles of surface water at the Okpu and Iyiowa-Odekpe sections of the River Niger in SouthEastern Nigeria were determined. Composites samples taken from surface water at three different locations (ST-1, ST-2, \& ST-3) for the months of June, September, December and February, were extracted with dichloromethane (DCM) by liquid-liquid partition and analyzed for TPH and aliphatic components using gas chromatography-flame ionization detection (GC-FID). The results reveal a TPH range of 1658.475-5435.742 $\mu \mathrm{g} / \mathrm{L}$ with a mean of $2596.523 \pm 492.466 \mu \mathrm{g} / \mathrm{L}$. The mean value for the raining season $(3283.783 \pm 1253.99 \mu \mathrm{g} / \mathrm{L})$ was significantly higher than that of the dry season $(1909.429 \pm 190.866 \mu \mathrm{g} / \mathrm{L})$. Values for all the months at all sampled locations were also much higher than the European Union (EU) standard limit of $300 \mu \mathrm{g} / \mathrm{L}$. Aliphatic hydrocarbon source diagnostics ratios gave range of: even to odd numbered n-alkanes ratio (0.162-2.371), carbon preference index -CPI (0.7021.581), sum of low molecular weight to high molecular weight $\mathrm{n}$-alkanes (0.0275-1.152), $\mathrm{nC} 31 / \mathrm{nC} 19(0.00-49.72)$, sum of long chain hydrocarbons to short chain hydrocarbons (0.824-38.03), and pristane/phytane ratio (ND-0.26); indicating that the TPH in the water were from both biogenic and anthropogenic inputs with biogenic sources that are largely terrestrial. This calls for necessary actions to reduce the anthropogenic inputs of TPH in the water so as to protect the aquatic ecosystem and sustain public health.

(C) 2021 International Scientific Organization: All rights reserved.

Capsule Summary: Current study determined the total petroleum hydrocarbons (TPH) content and aliphatic profiles of the River Niger surface water.

Cite This Article As: A. A. Chokor. Total petroleum and aliphatic hydrocarbons profile of the River Niger surface water at Okpu and Iyiowa-Odekpe regions in South-Eastern, Nigeria. Chemistry International 7(3) (2021) 188-196.

https://doi.org/10.5281/zenodo.4899763

\section{INTRODUCTION}

Total petroleum hydrocarbon (TPH) is a mixture of several hundreds of chemical compounds that originate from crude oil, and is largely made up of hydrogen and carbon, hence the name petroleum hydrocarbons. They are found in the range of $\mathrm{C}_{8}$ through $\mathrm{C}_{40}$ as mixture containing hundreds to thousands of hydrocarbons including aliphatic (straight carbon chain) and aromatic (carbon ring) compounds. Some hydrocarbon mixtures may also contain priority pollutants

including volatile organic compounds (VOCs), semi-volatile 
compounds (SVOCs) and metals, each of which have their own specific toxicity information (ATSDR, 1999; Inyang et al., 2018)

Though hydrocarbons are found naturally in the environment, large amount of it in a contaminated environment, which gets into water bodies through the activities of man such as: oil exploration and exploitation, pipelines leakages and vandalization, runoff from petroleum contaminated soils, leakages from farm tanks, tankers, trucks, vessels and ships, oil spills, and indiscriminate dumping of petroleum products on water ways. Sewage, municipal and industrial discharges, automobile wastes and vehicular emission arising from incomplete combustion carried by runoff and brought down to water bodies constitute other anthropogenic sources of TPH. Petroleum hydrocarbons in organisms and exposed individuals often result in numerous health implications such as: disruption in the activities of various body organs, severe damage to the pancreas, kidney, liver, blood circulatory system, and ultimately death (Abha and Singh, 2012; Oyinbo et al., 2018). Human health complications like carcinogenicity, genotoxicity, deoxyribonucleic acid (DNA) damage, birth defects, childhood leukaemia, infertility and miscarriages in women, sterility, skin rashes and irritation, respiratory system disorders, and cancer have also been associated with petroleum hydrocarbons contamination (Hurtig and Sabastian, 2002; Sudakin et al., 2011; Olawoyin et al., 2012; Ordinioha and Brisibe, 2013; Gudzenko et al., 2015; Ezekwe and Edoghotu, 2015; Kponee et al., 2015; Asghar et al, 2016, Briggs and Briggs, 2018; Ite et al., 2018).

The impact of petroleum hydrocarbons on the aquatic system and human health in general depends on the persistence and bioavailability of specific hydrocarbon, the ability of organisms to accumulate and metabolize various hydrocarbons, the fate of the metabolized products, and the interference of specific hydrocarbons with normal metallic processes (Lamardo et al., 2013; Lee et al., 2015). But generally, impairment of feeding mechanisms, growth rates, development rates, and increased susceptibility to diseases and other histopathological disorders are some subtle acute effects that may arise from exposure to petroleum hydrocarbons (Al-Shwafi 2008; Enuneku et al., 2015). Chronic low-level exposure to hydrocarbons may results in physiological impairment, affects survival and reduced reproductive success (Enuneku et al., 2015; Lee et al., 2015). The incidence of tumours in bottom dwelling fishes and shellfishes from petroleum contaminated coastal areas also suggest that petroleum hydrocarbons exposure and uptake have carcinogenic effects (Lee et al., 2015). In addition, hydrocarbons contamination of aquatic environment has adverse effects on recreation activities, aesthetics and tourism. This impact can be very significant on communities whose economy relies on tourism.

Total petroleum hydrocarbon (TPH), being a measurable amount of petroleum-based hydrocarbon in an environmental media, only measure gross (mixed) quantity. Thus, TPH itself is not a direct measure of risk to humans or the environment. It is however useful as a general indicator of petroleum contaminations in particular site. TPH values suggest relative potential for human exposure and therefore, the relative potential for human health effects. This work assessed the Total Petroleum Hydrocarbons (TPH) content in the water, and identified the source(s) of hydrocarbons using diagnostic ratios of the aliphatic profiles.

\section{MATERIAL AND METHODS}

\section{Study area}

The Niger is the third longest river in Africa, exceeded only by Nile and Congo River (also known as Zaire River). it is the major river in West Africa encompassing about 4,180 Km $(2,600 \mathrm{mi})$ with a drainage basin of about $2,117,700 \mathrm{Km}^{2}$ $(817,600 \mathrm{sq} \mathrm{mi})$ in area. It has its source from the Guinea Highlands in South-Eastern Guinea and passes through almost every climatic zone in West Africa. It runs in a crescent through Mali, Niger on the border with Benin and then through Nigeria discharging through a massive delta known as the Niger Delta into the Guinea Gulf of the Atlantic Ocean. The sample were taken in the vicinity of popular Niger Bridge which connects Okpu, Delta State (South-Southern Nigeria) and Iyiowa-Odekpe in Ogbaru local Government Area, Anambra State (South-Eastern Nigeria). Three composite water samples were collected at three different locations at some kilometres apart in the River and their coordinates were properly recorded viz: ST-1 (N06 $\left.{ }^{\circ} 7^{\prime} 17.93^{\prime \prime} \quad E^{\circ} 06^{\circ} 45^{\prime} 32.42^{\prime \prime}\right), \quad$ ST-2 (N06 05'42.66" E06 65'21.97"), and ST-3 (N06 $06^{\prime} 32.87^{\prime \prime}$ E06 $\left.{ }^{\circ} 44^{\prime} 02.66^{\prime \prime}\right)$. The river sides are characterized by activities such as: commercial market (Ogbo Agbada Market), sand dredging, commercial shipping, regular vehicular transportation activities including movement of trucks (Tippers). Indiscriminate disposal of waste on the river is also evident.

\section{Sample collection}

Composited samples were taken at the different locations of the river using 1 litre amber bottles well washed and dried. Piece of sterile aluminium foils were used to cover each bottle to prevent any sort of contamination. Thereafter, the bottles were covered tightly with plastic screw cover. The samples were cooled to $4^{\circ} \mathrm{C}$ and kept in ice parked cooler for onward transfer to the laboratory for analysis (Ikpe et al., 2016). Collections of samples were done in the month of June, September, December and February.

\section{TPH extraction}

Filtered water sampled were subjected to liquid - liquid extractions. One litre of water sample was placed in a 2-litre glass separatory funnel fitted with glass stopper and extracted with dichloromethane (DCM). The separating funnel was shaken vigorously for 3 minutes and pressure was released at intervals. The flask was allowed to stand for 
about 5 minutes allowing the organic layer to separate from the aqueous phase. The lower organic layer (extract) was then filtered through a funnel containing $5 \mathrm{~g}$ pack of anhydrous sodium sulphate to remove moisture from it. The extraction process was repeated trice for each sample and extracts were combined.

\section{Sample clean-up and detection}

Extracts from samples were concentrated using a rotary evaporator with water bath at $35^{\circ} \mathrm{C}$ and then subjected to silica gel clean-up and fractionation in order to remove polar organic components in the solvent and to separate the aliphatic and the aromatic components. Separation into aliphatic and aromatics was done by eluting $1.5 \mathrm{~mL}$ load of concentrated extract with $30 \mathrm{~mL}$ HPLC Hexane and $30 \mathrm{~mL}$ DCM respectively. The extracts were re-concentrated to about $2 \mathrm{~mL}$ and $1.5 \mathrm{~mL}$ of it was transferred into chromatographic vial and stored at $4^{\circ} \mathrm{C}$ awaiting the gas chromatography analysis. A gas chromatograph with flame ionization detector (GC-FID) was employed as described by Cortes et al (2012). A GC-FID model $5890 \mathrm{~N}$ gas chromatograph with flame ionization detector was used to analysed the sample for total petroleum hydrocarbon. The volume of sample injected was $1 \mu \mathrm{L}$ while the carrier gas was nitrogen at flow rate of $1.5 \mathrm{~mL} / \mathrm{min}$. samples were injected in split-less mode. The column used was DB-1, with dimension of $30 \mathrm{~m} \mathrm{X} 0.25 \mathrm{~mm} \times 0.25 \mu \mathrm{m}$. The column temperature was programmed with initial temperature $60{ }^{\circ} \mathrm{C}$ followed by increase at $8{ }^{\circ} \mathrm{C}$ per minute up to the final temperature of $300^{\circ} \mathrm{C}$. The injector and detector temperatures were set at
250 and $300^{\circ} \mathrm{C}$ respectively. The sum of all the aliphatic and aromatic hydrocarbons measured by GC-FID provides a measure of total petroleum hydrocarbon concentration.

\section{RESULTS AND DISCUSSION}

\section{Levels of TPH in the surface water}

Fig. 1 and Table 1 show the concentrations of TPH for the month of June, September, December, and February at the three sampling points (ST-1, ST-2, \& ST-3), as well as the calculated mean for the months and stations. There was no regular pattern in the concentrations of pollutant TPH; an indication that the pollutant was not coming from a point source but diverse sources. The mean values of TPH for the stations for the months of June, September, December, and

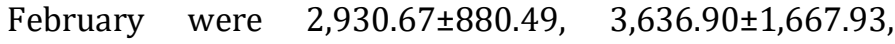
$1991.25 \pm 178.62$ and $1827.28 \pm 198.13(\mu \mathrm{g} / \mathrm{L})$, respectively. While the average concentrations for each station in all the months were: $2,493.781 \pm 817.205,3,148.283 \pm 1,634.583$, and $2,201.51 \pm 764.59(\mu \mathrm{g} / \mathrm{L})$. The mean for all the months samples at all stations was $2,596.52 \pm 492.47(\mu \mathrm{g} / \mathrm{L})$. Station 2 , had the highest mean $(3,148.28 \pm 1,639.58 \mu \mathrm{g} / \mathrm{L})$ for the months sampled, followed by station $1(2,439.78 \pm 817.21$ $\mu \mathrm{g} / \mathrm{L})$ and station $3(2,201.51 \pm 764.59 \mu \mathrm{g} / \mathrm{L})$ the least. The highest concentration $(5,435.74 \pm 60.85 \mu \mathrm{g} / \mathrm{L})$ was recorded in the month of September while the lowest $(1,658.48 \pm 23.86 \mu \mathrm{g} / \mathrm{L})$ was in February. The range for samples taken in the raining season (June and September) was 1951.72-5435.74 $\mu \mathrm{g} / \mathrm{L}$ with a mean of $3283.78 \pm 1253.99 \mu \mathrm{g} / \mathrm{L}$, while that for the dry season

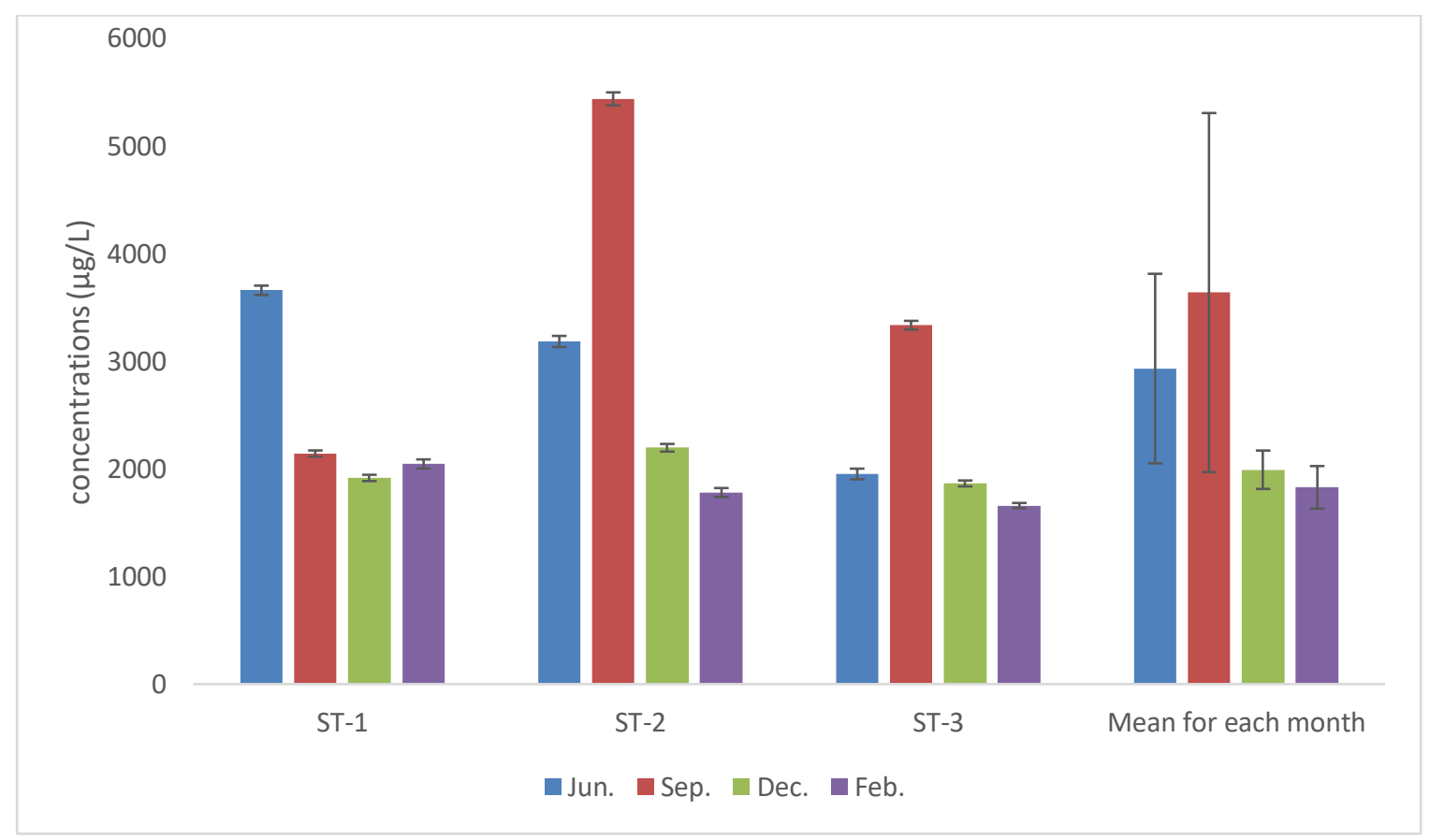

Fig. 1: Concentrations ( $\mu \mathrm{g} / \mathrm{L}$ ) of total petroleum hydrocarbons (TPH) in surface water at different stations in different months 
(December and February) was 1658.475-2195.345 $\mu \mathrm{g} / \mathrm{L}$ with a mean of $1909.43 \pm 190.87 \mu \mathrm{g} / \mathrm{L}$. Generally, the value for the dry season were less than that for the raining season. This could be as a result of the rain that normally washed down TPH from the land and road surfaces into the river. Also, the increased temperature during the dry season could have resulted in increased evaporations of TPH as well as photochemical degradation or decomposition of the same, with resultant effect of decreasing TPH concentrations in the water.

The TPH ranged from 1,658.47-5,435.74 $\mu \mathrm{g} / \mathrm{L}$ with a mean of $2,596.52 \pm 492.47 \mu \mathrm{g} / \mathrm{L}$ in the surface water. The range of this study is comparable to the 2,510.00-5,630.00 $\mu \mathrm{g} / \mathrm{L}$ reported for the Esi River, Western Niger Delta by Akporido and Onianwa (2015). The value is however, much lower than the $15,600-23,400 \mu \mathrm{g} / \mathrm{L}$ and 13,161.81$24,854.62 \mu \mathrm{g} / \mathrm{L}$ reported by Wokoma (2015) and Daniel and Nna (2016), respectively for TPH in subsurface seawater from the Kua/Kinabere creek, in Ogoni Landestuary of Bonny River and surface water in Cross River Estuary, Niger Delta. The value was also much lower than the 20,340-27,400 $\mu \mathrm{g} / \mathrm{L}$ observed by Adewuyi and Olowu (2012) for surface water within the vicinity of Nigeria National Petroleum Corporation (NNPC) depot in Apata, Ibadan. The mean of this study $(2,596.52 \mu \mathrm{g} / \mathrm{L})$ is much lower than the 73,500 $\mu \mathrm{g} / \mathrm{L}$ and $23,600 \mu \mathrm{g} / \mathrm{L}$ respectively recorded by Adewuyi et al (2011) and Clinton et al (2009), for surface water at Ubeji river, Warri, and oil polluted mangrove wetland of Niger Delta, Nigeria. Elsewhere, around the world, this value is comparable to the 25-2,759 $\mu \mathrm{g} / \mathrm{L}$ reported for the Strait of Johor, in Peninsula, Malaysia (Suratman, 2013), but much lower than the 60,000$260,000 \mu \mathrm{g} / \mathrm{L}$ recorded for the Deepwater Horizon, Gulf of Mexico (Sammarco et al., 2013). The values were however much higher than the 4-8 $\mu \mathrm{g} / \mathrm{L}$ reported for the Ethiope River, Delta, Nigeria by Ikpe et al (2016). It was also higher the 45.07-307 $\mu \mathrm{g} / \mathrm{L}$ and the 7.65-477.07 $\mu \mathrm{g} / \mathrm{L}$ reported by Adeniji et al (2017ab) for surface water in Algoa Bay and Buffalo River Estuary, both in Eastern Cape, South Africa respectively. Suratman (2012) and SOGRIL (2014) also reported range of 12-41 and 19-88 ( $\mu \mathrm{g} / \mathrm{L})$, respectively for the Dungan River Basin water, Malaysia, and the Levantine
Basin water of Israeli Coastline which were much below that of this study.

\section{Distributions of $\mathbf{n}$-alkanes and source identification}

The distributions of n-alkanes in the surface water are as shown in Table 2. The most dominant alkanes were $\mathrm{nC}_{8}-$ $\mathrm{nC}_{15}$, with exception $\mathrm{nC}_{10}$ in station $2, \mathrm{nC}_{15}$ and $\mathrm{nC}_{16}$ were largely present in station 2 , but were not detected in the other station. There was large presence of $\mathrm{nC}_{25}-\mathrm{nC}_{31}$ in all stations. The isoprenoid hydrocarbon-pristane was not detected in stations 1 and 2, but was found in station 3, likewise phytane was found in stations 2 and 3, but was undetected in station 1.

According to TPHCWG (1997), Gasoline Range Organic (GRO) generally includes $\mathrm{C}_{6}-\mathrm{C}_{10}$ hydrocarbon, while (DRO) Diesel Range Organic include hydrocarbon from $\mathrm{C}_{10}-\mathrm{C}_{28}$, the Oil Range Organic (ORO) range from $\mathrm{C}_{28}$ and above. In station 1, it was observed that the surface water was mostly contaminated with hydrocarbons whose range fall into the category of gasoline range organic (GRO) with C8 being the highest and diesel range organic (DRO), slight amount of lube oil range (ORO) was also detected. Hydrocarbons in the range of $\mathrm{C}_{35}-\mathrm{C}_{40}$ were not however, detected. In station 2, hydrocarbons contaminated with diesel range organic were detected except $\mathrm{C}_{10}$ and $\mathrm{C}_{22}$. The $\mathrm{nC}_{32}-\mathrm{C}_{40}$ range were not also detected except for $\mathrm{C}_{38}$. In station 3 , the $\mathrm{nC}_{28}-\mathrm{C}_{39}$ were detected except $\mathrm{C}_{31}, \mathrm{C}_{35}$, \& $\mathrm{C}_{36}$. Thus, station 3 is mostly contaminated with lube oil and diesel range organic excluding $\mathrm{C}_{16}-\mathrm{C}_{17}$. whereas, stations 1 and 2 were largely contaminated with hydrocarbons whose range fell into diesel range organic (DRO) and gasoline range organic (GRO). The observation in stations 1 (ST-1) and 2 (ST-2) could have resulted from the fact that these stations usually receive high concentration of hydrocarbons from vicinity of heavy trucks and vehicles from the overhead bridge; whereas the prevalence of $\mathrm{C}_{28}$ and above hydrocarbons in station 3 (ST-3) indicate that the fuel from ships engines must have contributed greatly to the TPH value of this station. This is evidenced by commercial shipping prevalent at this station.

Table 1: Concentrations ( $\mu \mathrm{g} / \mathrm{L})$ of TPH in surface water at different locations in different months

\begin{tabular}{lllllll}
\hline \multirow{2}{*}{ Locations } & \multicolumn{2}{c}{ Raining season } & \multicolumn{2}{c}{ Dry season } \\
& \multicolumn{1}{c}{ Jun. } & \multicolumn{1}{c}{ Sep. } & \multicolumn{1}{c}{ Dec. } & \multicolumn{1}{c}{ Feb. } & Range & Mean \\
\hline ST-1 & 3657.65 & 2141.57 & 1914.94 & 2044.97 & $1914.97-$ & $2439.78 \pm 817.20$ \\
& \pm 43.70 & \pm 28.91 & \pm 29.31 & \pm 42.32 & 3657.65 & \\
ST-2 & 3182.65 & 5435.74 & 2195.35 & 1779.40 & $1779.40-$ & $3148.28 \pm 1634.58$ \\
& \pm 51.68 & \pm 60.85 & \pm 35.50 & \pm 41.68 & 5435.74 & \\
ST-3 & 1951.71 & 3333.38 & 1863.45 & 1658.47 & $1658.47-$ & $2201.50 \pm 764.59$ \\
& \pm 49.53 & \pm 40.82 & \pm 27.54 & \pm 23.86 & 3333.38 & \\
Mean & 2930.67 & 3636.90 & 1991.24 & 1827.28 & $1827.28-$ & $2596.52 \pm 492.47$ \\
& \pm 880.44 & \pm 1667.93 & \pm 178.62 & \pm 198.13 & 3636.90 & \\
\hline
\end{tabular}

*ST: station 
Table 2: Aliphatic profiles of hydrocarbons in the surface water at different stations

\begin{tabular}{|c|c|c|c|}
\hline Components & $\begin{array}{c}\text { Station I. } \\
\text { Concentrations }(\mu \mathrm{g} / \mathrm{L})\end{array}$ & $\begin{array}{c}\text { Station II. } \\
\text { Concentrations }(\mu \mathrm{g} / \mathrm{L})\end{array}$ & $\begin{array}{c}\text { Station III. } \\
\text { Concentrations }(\mu \mathrm{g} / \mathrm{L})\end{array}$ \\
\hline $\mathrm{C}_{8}$ & 2534.791 & 1087.363 & 1268.567 \\
\hline $\mathrm{C}_{9}$ & 201.160 & 935.691 & 39.337 \\
\hline $\mathrm{C}_{10}$ & 100.717 & ND & 33.798 \\
\hline $\mathrm{C}_{11}$ & 161.330 & 170.441 & 74.659 \\
\hline $\mathrm{C}_{12}$ & 348.338 & 393.522 & 26.208 \\
\hline $\mathrm{C}_{13}$ & 127.354 & 75.266 & 63.788 \\
\hline $\mathrm{C}_{14}$ & 2.756 & 34.431 & 24.988 \\
\hline $\mathrm{C}_{15}$ & 0.579 & 63.390 & 4.223 \\
\hline $\mathrm{C}_{16}$ & ND & 34.191 & ND \\
\hline $\mathrm{C}_{17}$ & ND & 15.322 & ND \\
\hline Pristane & ND & ND & 0.344 \\
\hline $\mathrm{C}_{18}$ & 1.718 & 10.619 & ND \\
\hline Phytane & ND & 7.211 & 1.303 \\
\hline $\mathrm{C}_{19}$ & 0.405 & 1.444 & ND \\
\hline $\mathrm{C}_{20}$ & 0.509 & 2.395 & 0.573 \\
\hline $\mathrm{C}_{21}$ & 0.130 & 1.092 & ND \\
\hline $\mathrm{C}_{22}$ & 0.107 & ND & 0.222 \\
\hline $\mathrm{C}_{23}$ & ND & 0.380 & ND \\
\hline $\mathrm{C}_{24}$ & ND & 0.304 & ND \\
\hline $\mathrm{C}_{25}$ & ND & 0.538 & 1.526 \\
\hline $\mathrm{C}_{26}$ & 2.185 & 2.906 & 5.675 \\
\hline $\mathrm{C}_{27}$ & 3.218 & 6.119 & 9.317 \\
\hline $\mathrm{C}_{28}$ & 8.333 & 13.599 & 17.897 \\
\hline $\mathrm{C}_{29}$ & 14.085 & 21.786 & 27.278 \\
\hline $\mathrm{C}_{30}$ & 16.197 & 25.581 & 32.217 \\
\hline $\mathrm{C}_{31}$ & 20.126 & 38.268 & ND \\
\hline $\mathrm{C}_{32}$ & ND & ND & 41.850 \\
\hline $\mathrm{C}_{33}$ & ND & ND & 45.819 \\
\hline $\mathrm{C}_{34}$ & 22.209 & ND & 39.446 \\
\hline $\mathrm{C}_{35}$ & ND & ND & ND \\
\hline $\mathrm{C}_{36}$ & ND & ND & ND \\
\hline $\mathrm{C}_{37}$ & ND & ND & 95.752 \\
\hline $\mathrm{C}_{38}$ & ND & 133.214 & 29.368 \\
\hline $\mathrm{C}_{39}$ & ND & ND & 11.156 \\
\hline $\mathrm{C}_{40}$ & ND & ND & ND \\
\hline TAH & 3566.250 & 3075.073 & 1895.301 \\
\hline ¿РAH & 91.442 & 107.574 & 56.404 \\
\hline TPH & 3657.692 & 3182.546 & 1951.705 \\
\hline
\end{tabular}

*TAH: Total Aliphatic Hydrocarbons, ¿PAH: Total Poly Aromatic Hydrocarbons, TPH: Total Petroleum Hydrocarbons.

The wide-ranging abundance of low molecular weight hydrocarbons (less than $\mathrm{n}-\mathrm{C}_{23}$ ) suggested that the contaminant of this water may have been recent. This could have resulted from transportation activities, petroleum product spills, outboard and inboard boats engines as well as runoff from domestic waste and sewage discharge. Table 1 also shows that the Total Petroleum Hydrocarbons (TPH) in the surface water, was largely made up of aliphatic hydrocarbons as PAH (polyaromatic hydrocarbons) constituted only about 2.5-3.38 percent of TPH content.

Table 3 gives some source diagnostic ratios of hydrocarbons for the sampled sites. It reveals that ratio of sum of low molecular weight hydrocarbons to the sum of high molecular weight hydrocarbon was about one (1) in station 2 , but stations 1 and 3 clearly indicated large amount of high molecular weight hydrocarbon were present than are low molecular weight hydrocarbons. Thus, station 2 suggests anthropogenic input from petroleum source or fresh release, while stations 1 and 3 tend to reveals natural inputs from either higher plant, aquatic bacteria or marine animals. It has been reported that sum of low molecular weight hydrocarbons to the sum of high molecular weight hydrocarbon ( $\Sigma$ LMW $/ \Sigma \mathrm{HMW}$ ) ratios that are less than unity (1) typically connotes $n$-alkanes formed 
Table 3: Calculated aliphatic hydrocarbon source diagnostics ratios in the sampled stations

\begin{tabular}{cccc}
\hline Diagnostic indices & \multicolumn{3}{c}{ Stations } \\
\cline { 2 - 4 } & ST-1 & ST-2 & ST-3 \\
\hline ELMW/ EHMW & 0.037 & 1.153 & 0.027 \\
E/O & 2.37 & 0.162 & 1.408 \\
LHC/SHC & 38.03 & 0.824 & 8.665 \\
$\mathrm{nC31/nC19}$ & 49.72 & 26.50 & 0.00 \\
CPI & 1.083 & 1.582 & 0.702 \\
$\mathrm{Pr} / \mathrm{Ph}$ & 0 & $\infty$ & 0.26 \\
\hline
\end{tabular}

* $\varepsilon$ LMW/ $\Sigma$ HMW: sum of low molecular weight hydrocarbon to sum of high molecular weight hydrocarbon, E/O: even to odd hydrocarbons ratio, LHC/SHC: long chain to short chain hydrocarbons, CPI: carbon preference index, Pr/Ph: pristane over phytane ratio

by higher plants, marine animals and sedimentary bacteria, whereas, ratios of $\Sigma \mathrm{LMW} / \delta \mathrm{HMW}$ close to or greater than unity indicate $n$-alkanes that are largely from petroleum and plankton origins (Riccardia et al., 2008; Farid et al., 2014). However, the dominance of even numbered alkanes $\left(\mathrm{nC}_{16}, \mathrm{nC}_{18}, \mathrm{nC}_{20}\right)$ over odd ones $\left(\mathrm{nC}_{15}, \mathrm{nC}_{17}, \mathrm{nC}_{19}\right)$ in stations 1 and 3 , tended to support anthropogenic sources, likewise, the low ratio (less than one) of even-to-odd numbered alkanes in station 2 indicates biogenic inputs (Sakari et al., 2012; Adeniji et al., 2017a). It is therefore more likely that both natural and anthropogenic inputs contributed to the hydrocarbon content of the river water. The ratio of long chain hydrocarbons to short chain hydrocarbons was evaluated using relation shown in Eq. 1.

$\left[\sum \mathrm{nC}_{27}+\mathrm{nC}_{29}+\mathrm{nC}_{31} / \mathrm{EnC}_{15}+\mathrm{nC}_{17}+\mathrm{nC}_{19}\right]$

This ratio has been used to infer whether the hydrocarbons are from phytoplankton marine source or terrestrialvascular plants. High ratio greater than 4 indicated dominance of terrestrial plant waxes. Ratios within 0.210.80 suggests phytoplankton sources. While values between 2.38-4.33 implies mixture of both sources (Fagbote and Olanipekun, 2013; Adeniji et al., 2017a). The ratio obtained in this report: ST-1 (38.03), ST-2 (0.82), and ST-3 (8.66) tended to suggest that Stations 1 and 3 had hydrocarbons from terrestrial plants origin, while that in station 2 were from phytoplankton (marine) origin. However, the $\mathrm{nC}_{31} / \mathrm{nC}_{19}$ ratio which were 49.73 and 26.50 for stations 1 and 2, infer the predominance of hydrocarbons from terrestrial origin. This implies that both terrestrial and marine inputs contributed to the hydrocarbons' sources of the stations (station 2 inclusive). The $\mathrm{C}_{31} / \mathrm{C}_{19}$ ratio, has been used to index source of $\mathrm{n}$ alkanes in water. The presence of $\mathrm{nC}_{31}$ suggest terrestrial biogenic hydrocarbons, whereas $\mathrm{nC}_{19}$ indicate marine biogenic inputs. The ratio therefore, is used to indicate the dominance of either n-alkanes sources. Ratio below 0.4 represent marine sources while values above 0.4 is an indication of nonmarine or land derived hydrocarbons (Yusoff et al., 2012; Fagbote and Olanipekun, 2013; Adeniji et al., 2017b; Edori and Edori, 2021).
The carbon preference index (CPI) is a measure of the ratio of odd to even numbered carbon hydrocarbons calculated in different ways. It is useful in assessing the predominance of natural hydrocarbons over anthropogenic ones (Omayma et al., 2015; Abdallah et al., 2015). Values higher than one (especially in the range of 3-10) indicate biogenic sources (such as hydrocarbons from marine algae or terrestrial vascular plants) with dominance of odd numbered n-alkanes. Large presence of odd numbered hydrocarbons in the range of $\mathrm{nC}_{15}-\mathrm{nC}_{21}$ suggests the presence of $n$-alkanes from algae or microbial sources whereas, those in the range of $\mathrm{nC}_{23}-\mathrm{nC}_{31}$ indicates vascular plants source. However, values of CPI close to one (1) suggest hydrocarbons from petroleum inputs (Maioli et al., 2011; Onyema et al., 2013). This study reveals CPI range of $0.70-1.58$; an indication that the hydrocarbons had contributory source that originate from anthropogenic origin. The CPI is expressed in Eq. 2.

$\mathrm{CPI}_{25-33}=0.5 \times\left[\left(\mathrm{C}_{25}-\mathrm{C}_{33}\right) /\left(\mathrm{C}_{24}-\mathrm{C}_{32}\right)\right]+\left[\left(\mathrm{C}_{25}-\mathrm{C}_{33}\right) /\left(\mathrm{C}_{26}-\mathrm{C}_{34}\right)\right]$

Biogenic hydrocarbons are typified by the preponderance of pristane over phytane. Thus, phytoplankton inputs will result abnormally high pristane/phytane ratio (Abdallah et al., 2015). The ratio obtained in this study ranges from 0.00-0.26 indicating largely a petrogenic contamination (Kaur et al., 2017; Orta-Martínez et al., 2018; Schwarz et al., 2019).

\section{CONCLUSIONS}

The study was carried out to determine the level of petroleum hydrocarbon in Okpu and Iyiowa-Odekpe sections of the River Niger in South-Eastern Nigeria. The results reveal a range of $1658.475-5435.742 \mu \mathrm{g} / \mathrm{L}$ with a mean of $2596.523 \pm 492.466 \mu \mathrm{g} / \mathrm{L}$ which was much higher than the European Union standard limit of $300 \mu \mathrm{g} / \mathrm{L}$. Aliphatic profile and source identification analysis show that the hydrocarbons content in the water were from both biogenic and anthropogenic inputs; with the biogenic inputs been largely terrestrial. The relatively high value of TPH calls for concern as there is strong probability of their accumulation in sediments and aquatic organisms that will ultimately 
impact public health. Therefore, concerted effort is necessary to reduce the anthropogenic inputs of the TPH in the water in order to maintain a balanced healthy ecosystem and protect public health.

\section{REFERENCES}

Abdallah, R.I., Khalil, N.M., Roushdie, M.I., 2015. Monitoring of pollution in Egyptian red sea. Egyptian Journal of Petroleum 24, 59-70.

Abha, S., Singh, C.S., 2012. Hydrocarbon pollution: effects on living organisms' remediation of contaminated environments, and effects of heavy metals cocontamination on bioremediation. In: Introduction to Enhanced Oil Recovery (EOR) Processes and Bioremediation of Oil-Contaminated Sites, pp. 186-206.

Adeniji, A., Okoh, O., Okoh, A., 2017. Petroleum hydrocarbon fingerprints of water and sediment samples of Buffalo River Estuary in the Eastern Cape Province, South Africa. Journal of Analytical Methods in Chemistry 2017, 1-10.

Adeniji, A.O., Okoh, 0.0., Okoh, A.I., 2017a. Petroleum hydrocarbon profiles of water and sediment of Algoa Bay, Eastern Cape, South Africa. International Journal of Environmental Research and Public Health 14, 1263.

Adewuyi, G.O., Etchie, O.T., Ademoyegun, O.T., 2011. Determination of total petroleum hydrocarbons and heavy metals in surface water and sediment of Ubeji River, Warri, Nigeria. Bioremediation, Biodiversity and Bioavailability 5(1), 46 -51.

Adewuyi, G.O., Olowu R.A., 2012. Assessment of oil and grease, total petroleum hydrocarbons and some heavy metals in surface and groundwater within the vicinity of NNPC oil Depot in Apata, Ibadan Metropolis. Nigeria. International Journal of Research and Reviews in Applied Sciences 13, 166 - 174.

Aguilera, F., Méndez, J., Pásaro, E., Laffon, B., 2010. Review on the effects of exposure to spilled oils on human health. Journal of Applied Toxicology 30 (4), 291-301.

Akporido, S.O., Onianwa, P.C., 2015. Heavy metals and total petroleum hydrocarbon concentration in surface water of Esi River, western Niger Delt. Research Journal of Environmental Sciences 9, 88-100.

Al-Shwafi, N. A. A. 2008. Total petroleum hydrocarbon carcinogens in commercial fish in the red sea and Gulf of Aden-Yemen. Marine Science 19, 15-28.

Asghar, H.N., Rafique, H.M., Zahir, Z.A., Khan, M.Y., Akhtar, M.J., Naveed, M., Saleem, M., 2016. Petroleum hydrocarbons-contaminated soils: remediation approaches, Soil science: agricultural and environmental prospectives. Springer, pp. 105-129.
ATSDR, 1999. Toxicological profile for total petroleum hydrocarbon, Agency for Toxic substances and Disease Registry (ATSDR). Atlanta, GA: US. Department of Health and Human Services, Public Health Services.

Briggs, I. L., Briggs, B.C., 2018. Petroleum industry activities and human health A2-Ndimele, Prince E," The political ecology of oil and gas activities in the nigerian aquatic ecosystem, Ndimele, P.E. ed., Academic Press, pp. 143147.

Clinton, H.I., Ujagwung, WU., Horsfall, M., 2009. Evaluation of total hydrocarbon levels in some aquatic media in an oil polluted mangrove wetland in the Niger Delta. Applied Ecology and Environmental Research 7, 111-120.

Cortes, J.E., Suspes, A., Roa, S., Gonzalez, C., Castro, H.E., 2012. Total petroleum hydrocarbons by gas chromatography in Colombian waters and soils, American Journal of Environmental Sciences 8, 396-402.

Daniel, I.E., Nna, P.J., 2016. Total petroleum hydrocarbon concentration in surface water of cross River Estuary, Niger Delta, Nigeria. Asian Journal of Environment \& Ecology 1, 1-7.

Edori, E.S., Edori, O.S., 2021. Fingerprints of total petroleum hydrocarbons in the water and sediments of Onyima Creek (Ede Onyima), Engenni Ahoada West, Rivers State, Nigeria. Global Journal of Science Frontier Research: $(\mathrm{H})$ Environment and Earth Science 21, 1-11

Enuneku, A.A., Ainerua M., Erhunmwunse, N.O., Osakue O.E., 2015. Total petroleum hydrocarbons in organs of commercially available fish; Trachurus Trecae (Cadenat, 1949) from Oliha Market, Benin City, Nigeria. Ife Journal of Science 17, 383-393.

Ezekwe, C.I., Edoghotu, M.I., 2015. Water quality and environmental health indicators in the Andoni River estuary, Eastern Niger Delta of Nigeria. Environmental Earth Sciences 74, 6123-6136.

Fagbote, O.E., Olanipekun, E.O., 2013. Characterization and sources of aliphatic hydrocarbons of the sediments of River Oluwa at Agbabu Bitumen deposit area, Western Nigeria. Journal of Scientific Research and Reports 2, 228-248.

Farid, N.A., Mahmoud, S.A., Ahmed, O.E., 2014. Assessment of Contamination by Petroleum Hydrocarbons in Sediments along Discharge Basin of Suez Oil Refinery Company, Southwest of the Suez Gulf. Egyptian Journal of Chemistry 57, 75-96.

Ghorani-Azam, A., Riahi-Zanjani, B., Balali-Mood, M., 2016. Effects of air pollution on human health and practical measures for prevention in Iran. Journal of Research in Medical Sciences: The Official Journal of Isfahan University of Medical Sciences 21, 65. 
Gudzenko, N., Hatch, M., Bazyka, D., Dyagil, I., Reiss, R.F., Brenner, A., Chumak, V., Babkina, N., Zablotska, L.B., Mabuchi, K., 2015. Non-radiation risk factors for leukaemia: A case-control study among chornobyl cleanup workers in Ukraine. Environmental Research 142 (Supplement C), 72-76.

Hurtig, A. K., San Sebastian, M., 2002. Geographical differences in cancer incidence in the Amazon basin of Ecuador in relation to residence near oil fields. International Journal of Epidemiology 31, 1021-1027.

Ikpe, E.E., Akpakpan, A.E., Nsi, E.W., Ekanem, A.N., 2016. Determination of the level of petroleum hydrocarbon in water, fishes and plants from part of River Ethiope, Oghara in Delta State, Nigeria. International Journal for Research in Applied and Natural Science 2, 1-10.

Ite, A.E., Harry, T.A., Obadimu, C.O., Asuaiko, E.R., Inim, I.J., 2018. Petroleum hydrocarbons contamination of surface water and groundwater in the Niger Delta region of Nigeria. Journal of Environment Pollution and Human Health 6(2), 51-61. doi: 10.12691/jephh-6-2-2.

Kaur, N., Erickson, T.E., Ball, A.S., Ryan, M.H., 2017. A review of germination and early growth as a proxy for plant fitness under petrogenic contamination - knowledge gaps and recommendations. Science of The Total Environment 603-604, 728-744.

Kponee, K. Z., Chiger, A., Kakulu, I. I., Vorhees, D., HeigerBernays, W., 2015. Petroleum contaminated water and health symptoms: a cross-sectional pilot study in a rural Nigerian community. Environmental Health 14, 86.

Lee, K., Boufadel, M., Chen, B., Foght, J., Hodson, P., Swanson, S., Venosa, A., 2015. Expert panel report on the behaviour and environmental impacts of crude oil released into aqueous environments. Royal Society of Canada, Ottawa, ON. ISBN: 978-1-928140-02-3.

Maioli, O.L.G., Rodrigues, K.C., Knoppers, B.A., Azevedo, D.A., 2011. Distribution and sources of aliphatic and polycyclic aromatic hydrocarbons in suspended particulate matter in water from two Brazilian estuarine systems. Continental Shelf Research 31, 1116-1127.

Olawoyin, R., Larry Grayson, R., Okareh, O.T., 2012. Ecotoxicological and epidemiological assessment of human exposure to polycyclic aromatic hydrocarbons in the Niger Delta, Nigeria. Toxicology and Environmental Health Sciences 4, 173-185.

Omayma, E.A., Sawsan, A.M., Abd El Rahman, M., 2015. Monitoring and Assessment of Petroleum Hydrocarbons in Surface Seawater along Alexandria Coasts, Egypt. International Journal of Environment 4, 70-86.

Onyema, M., Osuji, L., Ofodile, S., 2013. Geochemical fingerprinting of an oil-impacted site, Niger Delta: source and weathering profile of aliphatic hydrocarbons. Researcher 5, 16-21.

Ordinioha, B., Brisibe, S., 2013. The human health implications of crude oil spills in the Niger delta, Nigeria: An interpretation of published studies. Nigerian Medical Journal 54, 10 - 16.

Orta-Martínez, M., Rosell-Melé, A., Cartró-Sabaté, M., O'Callaghan-Gordo, C., Moraleda-Cibrián, N., Mayor, P., 2018. First evidences of Amazonian wildlife feeding on petroleum-contaminated soils: A new exposure route to petrogenic compounds? Environmental Research 160, 514-517.

Oyibo, J.N., Wegwu, M.O., Uwakwe, A.A., Osuoh, J.O., et al., 2018. Analysis of total petroleum hydrocarbons, polycyclic aromatic hydrocarbons and risk assessment of heavy metals in some selected fin fishes at Forcados Terminal, Delta State, Nigeria. Environmental Nanotechnology, Monitoring and Management 9, 128135.

Riccardia, C., Filippoa, P.D., Pomataa, D., Incoronatoa, F., Basilioa, M.D., Papinib, M.P., Spicagliaa, S., 2008. Characterization and distribution of petroleum hydrocarbons and heavy metals in groundwater from three Italian tanks farms. Science of the Total Environment 393, 50-63.

Sakari, M., Zakaria, M.P., Lajis, N.H., Mohamed, C.A.R., Abdullah, M.H., 2012. Reconstruction of aliphatic hydrocarbon history and sources from sedimentary record of the Johor Strait, Malaysia. Coastal marine science 35, 142-152.

Sammarco, P.W., Kolian, R.S., Warby, A.R., Bouldin, L.J., Subra, W.A., Porter, S.A., 2013. Distribution and concentrations of petroleum hydrocarbons associated with the BP/Deepwater Horizon Oil Spill, Gulf of 108 Mexico. Marine Pollution Bulletin73, 129-143.

Schwarz, A., Adetutu, E.M., Juhasz, A.L., Aburto-Medina, A., Ball, A.S., Shahsavari, E., 2019. Response of the fungal community to chronic petrogenic contamination in surface and subsurface soils. Geoderma 338, 206-215.

SOGRLI, 2014. Final Report: Yam-3 Environmental Monitoring Post-Drill Survey Report, CSA Ocean Sciences, Shemen Oil and Gas Resources Israel (SOGRLI), Stuart, Fla, USA.

Sudakin, D.L., Stone, D.L., Power, L., 2011. Naphthalene Mothballs: Emerging and Recurring Issues and their Relevance to Environmental Health. Current Topics in Toxicology 7, 13-19.

Suratman, S., 2013. Distribution of total petrogenic hydrocarbon in Dungun River Basin, Malaysia. Oriental Journal of Chemistry 29, $77-80$. 
Suratman, S., Tahir, N.M., Latif, M.T., 2012. A Preliminary study of total petrogenic hydrocarbon distribution in Setiu Wetland, Southern South China Sea (Malaysia). Bulletin of Environmental Contamination and Toxicology 88, 755-758.

TPHCWG, 1997. Selection of representative TPH fractions based on fate and transport considerations, total petroleum hydrocarbon criteria working group (TPHCWG) series, (John B. Gustafson, Ph.D.; Joan Griffith Tell, Ph.D. and Doug Orem). 3, http://www.aehs.com/

Wokoma, O.A.F., 2014. Levels of total hydrocarbon in water and sediment of a polluted tidal creek, Bonny River, Niger Delta Nigeria. International Journal of Scientific \& Technology Research 3, 351-354.

Yusuff, H.B., Assim, Z.B., Mohamad, SB., 2012. Aliphatic hydrocarbons in surface sediments from South China Sea of Kuching Division, Sarawak. The Malaysia Journal of Analytical Sciences 16, 1-11.

Visit us at: http://bosaljournals.com/chemint/

Submissions are accepted at: editorci@bosaljournals.com 